\title{
Coastal erosion risk assessment in the coastal area of Muara Asam Asam, Tanah Laut Regency
}

\author{
Rizki Adriadi Ghiffari ${ }^{*}$ and Haryo Dwito Armono ${ }^{2}$ \\ ${ }^{1}$ Department of Development Geography, Faculty of Geography, Universitas Gadjah Mada, Yogyakarta, Indonesia \\ ${ }^{2}$ Marine Engineering Department, Faculty of Marine Technology, Institut Teknologi Sepuluh Nopember, Surabaya, Indonesia
}

\begin{abstract}
Coastal erosion is the process of land erosion in coastal areas due to waves and ocean currents which reduce land and can adversely affect socio-economic activities in coastal areas. Coastal erosion risk assessment in the estuary is a development of previous research, because the erosion and accretion processes do not only occur along the shoreline, but also on the side facing river water bodies, due to the confluence of fluvial and marine processes. The landward shift of the shoreline in the Muara Asam Asam coastal area has reached 90 meters in the last 28 years, and has been detrimental because the area is a densely populated area with major economic activities in the fisheries and agriculture sectors. This study aims to determine the coastal erosion risk level zones based on the relationship among vulnerability and consequence parameters, through distance decay weighted based method. The results indicate that Muara Asam Asam has high risk zones of coastal erosion, especially in densely populated residential areas and dry land agriculture on the west side of the estuary, due to the lack of implementation of preventive measures through hard coastal structure and coastal zoning policy to protect socio-economic activities and coastal ecological environments.
\end{abstract}

\section{Introduction}

The coastal area is a very important environment for the community, because it supports a large number of activities related to fishing, navigation, trade and tourism. Therefore most of the world's population lives in coastal areas, including most important cities, also in coastal areas [1].

The presence of anthropogenic processes in coastal areas raises concerns related to hazards affecting coastal areas such as tidal waves, storms, tidal flooding, coastal erosion, and sea level rise. To address the potential consequences of these hazards, several methods for assessing the level of vulnerability and risk of coastal erosion have been developed. Since 1991, when the IPPC general method was presented [2], vulnerability and risk assessments have continued to be developed, such as videotape-assisted based vulnerability analysis [3], coastal vulnerability index [4], the smart line approach [5], the coastal area simulator [6], and the latest is the coastal area risk assessment framework [7].

In its basic definition, risk must be understood as an estimate of the consequences of a particular event [8]. On the other hand, in the risk assessment of coastal areas, the occurrence of coastal erosion is defined as a hazard, which is a hazardous phenomenon that can cause loss of life, injury or other health impacts, property damage, loss of livelihood and public service facilities, social and economic disruption, or environmental damage [9].

Therefore, the assessment of the risk of coastal erosion depends on the likelihood and level of hazard density and the hazard consequences of a coastal erosion event [10]. For coastal areas, the negative impacts of hazards are expressed in terms of human, economic and environmental impacts, as well as social / political impacts. Vulnerability reveals the characteristics and conditions of the community, system or asset that make it vulnerable to damage caused by coastal erosion hazards [9]. Coelho (2005) developed a methodology for assessing the risk of coastal erosion. This method was chosen in this study because there is no other complex model which in its formulation allows for rapid application at the research site by adjusting the number and detail of parameters based on the availability of field data.

The coastal erosion phenomena in Muara AsamAsam Village has entered an increasingly severe stage, due to the destruction of mangrove forests which have been used as coastal protection plants, as well as the opening and expansion of ponds and other agricultural land [11]. Coastal erosion in this area is also influenced by sediment transport activity generated by currents and waves due to seasons and winds. The occurrence of longshore currents that distribute sediment, so that in some locations there is coastal erosion, and in other locations there is accretion / sedimentation.

The incidence of extreme coastal erosion began in early 1983 (Results of Interview with Village Officials). Moreover, in the time period until this study was carried out, the impact of this disaster had significantly affected people's lives and livelihoods.

The aim of this study is to identify the coastal erosion risk zones according to the characteristics of

\footnotetext{
* Corresponding author: rizki.adriadi.g@ugm.ac.id
} 
vulnerability and consequences. This classification aims to support decision-making in accordance with the characteristics of the area, and the identification of areas that need more attention (priority zones) in the face of coastal erosion hazards.

\section{Method}

This study uses the methodology proposed by Coelho (2005) to assess vulnerability, consequences and risks associated with coastal erosion. This method is focuses specifically on coastal erosion, rather than most of other methods that generally concerned on sea level rise [12]. Apart from being easy to modify, such as changing the weight of each parameter or changing its parameters, this method also can be implemented in various geographic information system software, making it easy to access in spatial analyzes related to coastal area management.

Coastal erosion risk assessment divides into two parts. The first is a vulnerability assessment that estimates, qualitatively and quantitatively, the level of vulnerability of a coastal area to coastal erosion [13]. This assessment focuses on the physical characteristics of the coastal area and the potential threats to erosive agents. The second part is an assessment of the consequences of the hazard event, by looking at the social, environmental, cultural and economic aspects in the study area [13].

The data collection stage consists of the acquisition of a digital elevation map that is stereopair extracted from aerial photographs acquired via an unmanned aerial vehicle (UAV), which are then used for the preparation of topographic maps. In addition, measurements of wave height and tidal range along the shoreline and river estuaries are also carried out as part of the vulnerability parameters.

Some of the parameters are obtained from secondary data extraction such as geological parameters derived from the interpretation of the geological map. The spatial pattern plan and land use map from the Regional Spatial Plan of Tanah Laut Regency are used to be extracted into ecological parameters, historical sites and land cover. Meanwhile, there is the use of Landsat 5,7,8 satellite imagery to obtain the value of the annual average coastal erosion / accretion rate parameter. Specifically for this parameter, the data is processed through The Digital Shoreline Analysis System (DSAS) software, so that it can analyze spatial statistics, any changes to the shoreline every year from 1989 to 2021.

Other data such as geomorphology, anthropogenic action, population density and economic level are interpreted based on the appearance of the UAV photo image, which is compared with the statistical data of Jorong District in Figures of 2021, as well as the results of field observations when taking the tie point of aerial photo images.

\section{Result and discussion}

\subsection{Study area}

The research area is a coastal area of Asam Asam River Estuary, Muara Asam Asam Village which is located in Jorong District, Tanah Laut Regency, South Kalimantan Province, shown in figure 1. Asam Asam Village is one of the oldest settlements in Tanah Laut where the majority of the population is the Banjar Tribe. The name of this village is already in the Hikayat Banjar which was written in 1663 which is referred to as Hasam Hasam [14].

Based on its physical characteristics, this village is located at the estuary of the Asam Asam river, precisely on land formed by sediment from the confluence of fluvial energy from the river and the energy of ocean currents [15]. With these unique characteristics, the coastal area of Muara Asam Asam Village changes significantly every year, both by the incidence of coastal erosion and accretion [16]. This is important to study considering there are thousands of villagers whose homes in densely populated area that are in risk of coastal erosion.

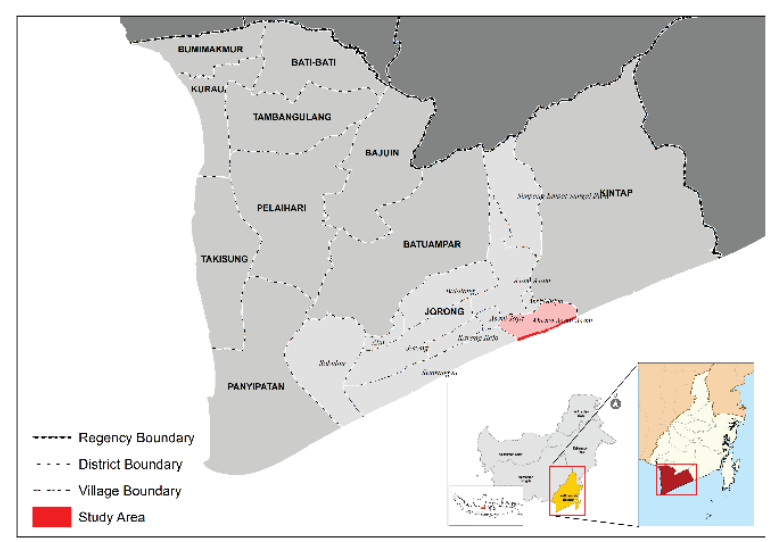

Fig. 1. Study area orientation map

\subsection{Vulnerability assessment}

Data from each parameter in the level of vulnerability analysis is classified first based on the classification rules presented in Table 1. After that, all parameters are inputted in the CERA application to perform raster operations using the Map Algebra method according to the weight calculation algorithm presented in Table 2. Distance decay principle is used to determine the different weight on each value of each parameter based on their pythagorean distance to the shoreline. 
Table 1. Classification of vulnerability parameters

\begin{tabular}{|c|c|c|c|c|c|c|}
\hline \multirow{2}{*}{ No } & \multirow{2}{*}{ Parameter } & \multicolumn{5}{|c|}{ Level of Vulnerability } \\
\hline & & Very Low & Low & Moderate & High & Very High \\
\hline 1 & Distance to shoreline (m) & $>1000$ & $\begin{array}{l}200- \\
1000\end{array}$ & $50-200$ & $20-50$ & $<20$ \\
\hline 2 & Topography (m) & $>30$ & $20-30$ & $10-20$ & $5-10$ & $<5$ \\
\hline 3 & Geology & Igneous rocks & $\begin{array}{l}\text { Metamor } \\
\text { phic } \\
\text { rocks }\end{array}$ & $\begin{array}{l}\text { Sedimenta } \\
\text { ry rocks }\end{array}$ & $\begin{array}{l}\text { Coarse } \\
\text { textured } \\
\text { sediments }\end{array}$ & $\begin{array}{l}\text { Smooth } \\
\text { textured } \\
\text { sediments }\end{array}$ \\
\hline 5 & Geomorphology & Mountains & $\begin{array}{l}\text { Rocky } \\
\text { cliffs }\end{array}$ & $\begin{array}{l}\text { Eroded } \\
\text { cliffs that } \\
\text { extend } \\
\text { along the } \\
\text { shoreline }\end{array}$ & $\begin{array}{l}\text { Beaches, } \\
\text { fluvio marin } \\
\text { plains }\end{array}$ & $\begin{array}{l}\text { sand dunes, } \\
\text { estuaries }\end{array}$ \\
\hline 6 & Land cover & Forests & $\begin{array}{l}\text { Agricultu } \\
\text { ral crops }\end{array}$ & Bare lands & $\begin{array}{c}\text { Rural } \\
\text { settlements }\end{array}$ & $\begin{array}{c}\text { Urban } \\
\text { settlements, } \\
\text { industrial } \\
\text { areas }\end{array}$ \\
\hline 7 & Anthropogenic actions & $\begin{array}{l}\text { Intervention } \\
\text { on shoreline } \\
\text { stabilization }\end{array}$ & $\begin{array}{l}\text { Interventi } \\
\text { on } \\
\text { without } \\
\text { reduction } \\
\text { of } \\
\text { sediment } \\
\text { sources }\end{array}$ & $\begin{array}{l}\text { Interventio } \\
\mathrm{n} \text { with } \\
\text { reduction } \\
\text { of } \\
\text { sediment } \\
\text { sources }\end{array}$ & $\begin{array}{c}\text { Without } \\
\text { intervention } \\
\text { or reduction } \\
\text { of sediment } \\
\text { sources }\end{array}$ & $\begin{array}{l}\text { Without } \\
\text { intervention } \\
\text {, but still } \\
\text { any } \\
\text { reduction in } \\
\text { sediment } \\
\text { sources }\end{array}$ \\
\hline 8 & $\begin{array}{l}\text { Maximum significant } \\
\text { wave height }(\mathrm{m})\end{array}$ & $<3$ & $3-5$ & $5-6$ & $6-6,9$ & $>6,9$ \\
\hline 9 & $\begin{array}{l}\text { Maximum tide distance } \\
\text { (m) }\end{array}$ & $<1$ & $1-2$ & $2-4$ & $4-6$ & $>6$ \\
\hline 10 & $\begin{array}{l}\text { Annual average on } \\
\text { coastal erosion/accretion } \\
\text { rate ( } \mathrm{m} / \text { year) }\end{array}$ & $\begin{array}{c}>0 \\
\text { (Accretion) }\end{array}$ & $\begin{array}{l}(-1)-0 \\
(\text { Erosion})\end{array}$ & $\begin{array}{l}(-3)-(-1) \\
(\text { Erosion})\end{array}$ & $\begin{array}{l}(-5)-(-3) \\
\text { (Erosion) }\end{array}$ & $\begin{array}{c}<(-5) \\
(\text { Erosion })\end{array}$ \\
\hline
\end{tabular}

Table 2. The weight of each parameter of the level of vulnerability, based on its distance to the shoreline

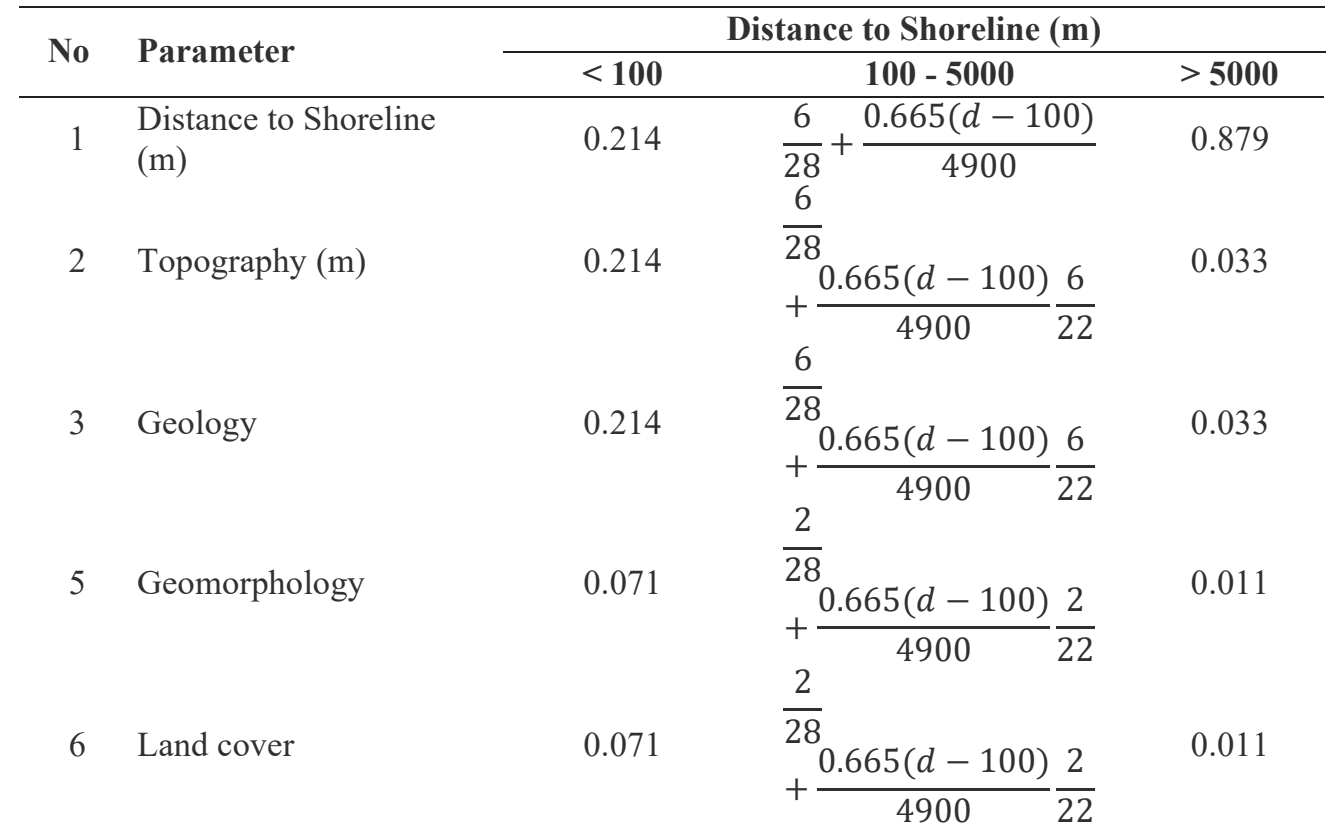




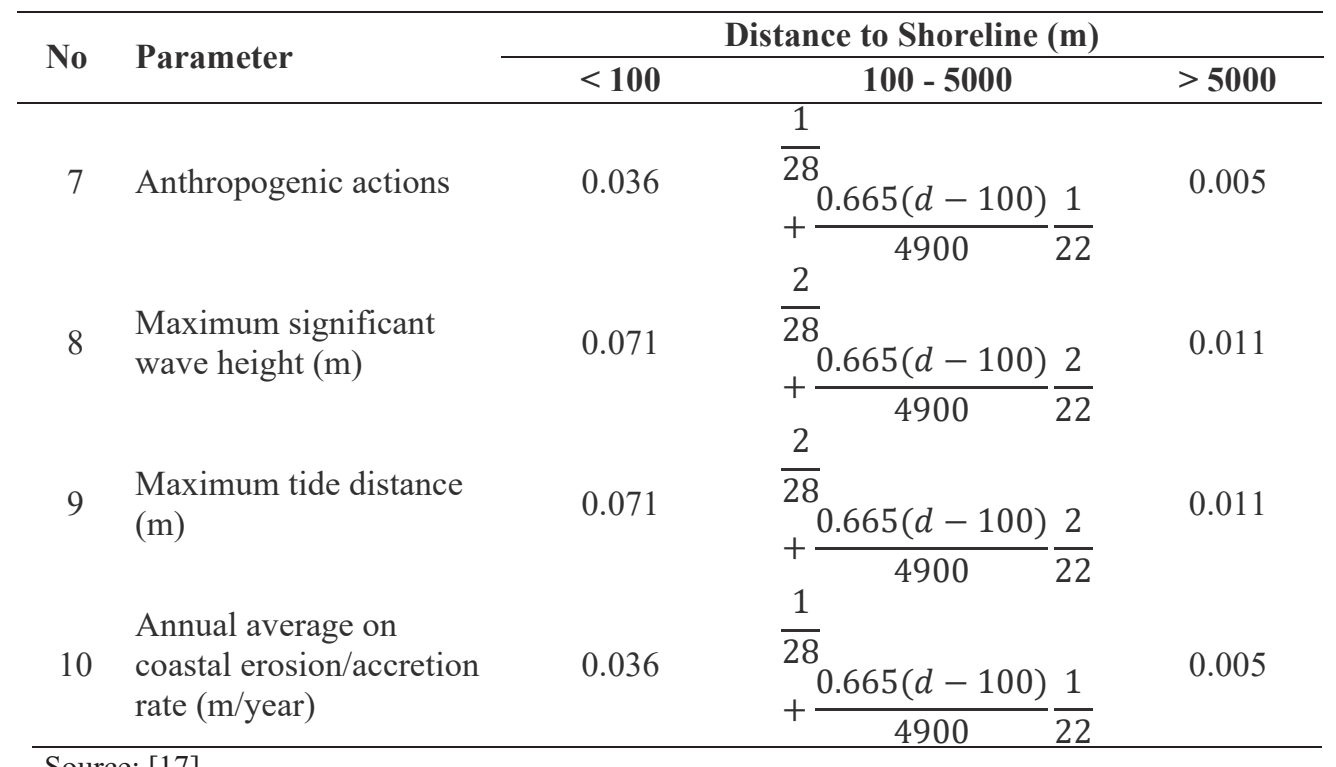

Source: [17]

Based on the results of field measurements, the highest tide distance of sea water on the coast of Muara Asam-Asam Village is a maximum of 2 meters from the coastline, this includes low classification in the level of vulnerability to coastal erosion. Parts of the river close to the estuary are also affected by tides, but only at a maximum level of $1 \mathrm{~m}$ or classified as very low in terms of coastal erosion vulnerability

The maximum wave height on the coast around Muara Asam-Asam Village is in the medium category, because it ranges from 5-6 $\mathrm{m}$ in bad weather conditions. This of course will greatly affect the level of vulnerability of community activity zones along the coastline, because the movement of wave energy is also sometimes followed by mass movements of ocean currents that can erode the shoreline or carry sediment in the form of sediment from the seabed.

Basically, the coastal area of Muara Asam Asam Village has similar topographic characteristics because it has a land elevation ranging from $1-4 \mathrm{~m}$ above sea level and with a gentle slope to flat $(0-2 \%)$. This is because almost all of the land in this area is formed by sediment deposits from the sea and rivers, not through tectonic or denudational processes.

Based on the results of the shoreline change analysis through the DSAS software, it was found that along the shoreline of Muara Asam Asam Village, there were varied levels of erosion and accretion when viewed from the trend of shoreline changes between 1989-2017. The part with the highest level of erosion is around the center of the settlement of Muara Asam Asam Village, which is located some distance from the estuary, as well as the eastern part of the river estuary. This is an indication of the movement of the dominant ocean currents from the southwest to the northeast, thus diverting the river flow and forming an estuary on the east side. In fact, based on the identified trends, there is a tendency for river estuaries to move as far as $90 \mathrm{~m}$ to the east in a period of 28 years, which means that if this trend continues, new land will emerge on the eastern side of the settlement center of Muara Asam Asam Village, and vice versa, the east side. the estuary which is an agricultural area and open land will be eroded to become part of the river estuary.

In general, the coastal area of Muara Asam Asam Village is dominated by densely populated residential areas on the west side of the river, and open land and shrubs on the east side of the river. This makes the western region more vulnerable and at risk of coastal erosion than the eastern region.

Anthropogenic action consists of efforts to reduce erosion rates and coastal accretion. Based on the results of field observations, there is a coastal construction that is parallel to the coastline and functions in reducing the kinetic energy of waves and ocean currents, in the form of a wave breaker. This construction performance is less than optimal due to its proper placement in the middle of the tidal area, so that the erosion of the pan still occurs because the waves break before meeting the breakwater, even in some locations, the breakwater that has been installed is then buried in the sand due to tidal energy and sea waves. However, for the analysis the level of vulnerability for the presence of breakwaters is classified as low, because it is better than other locations in the study area without any protection against coastal erosion.

The results of the level of vulnerability analysis produced a map of the level of vulnerability to coastal erosion in Muara Asam Asam Village which can be seen in Figure 2. 


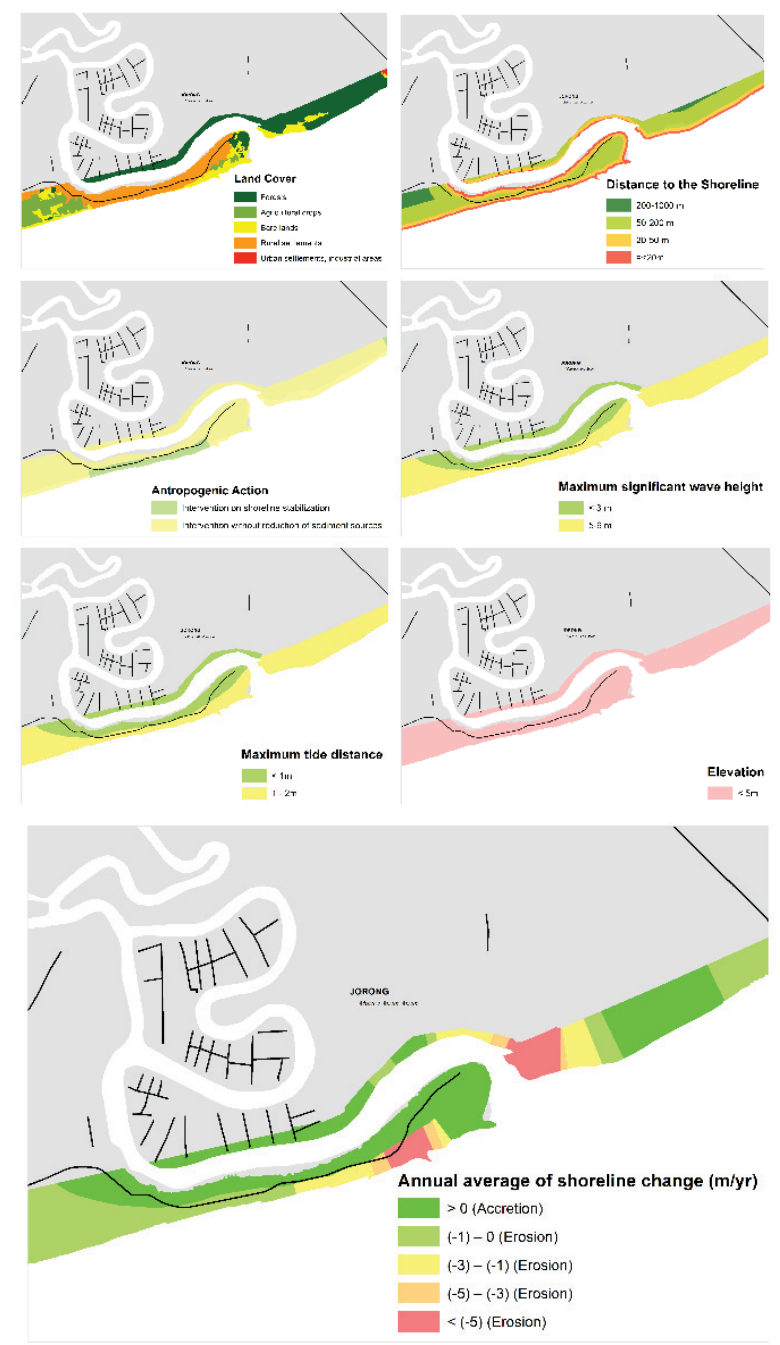

Fig. 2. Coastal erosion vulnerability assessment parameters

Based on the results of the analysis of the level of vulnerability, it was found that the zones with a high level of vulnerability were almost evenly spread across the coast of Muara Asam Asam Village with different distances to the mainland (Figure 3). The zone with the highest very high vulnerability level is located in the center of the settlement facing the sea and near the river estuary, in contrast to the eastern side near the industrial area which has a smaller area of very high vulnerability. Meanwhile, the other sections are classified into high and medium levels of vulnerability.

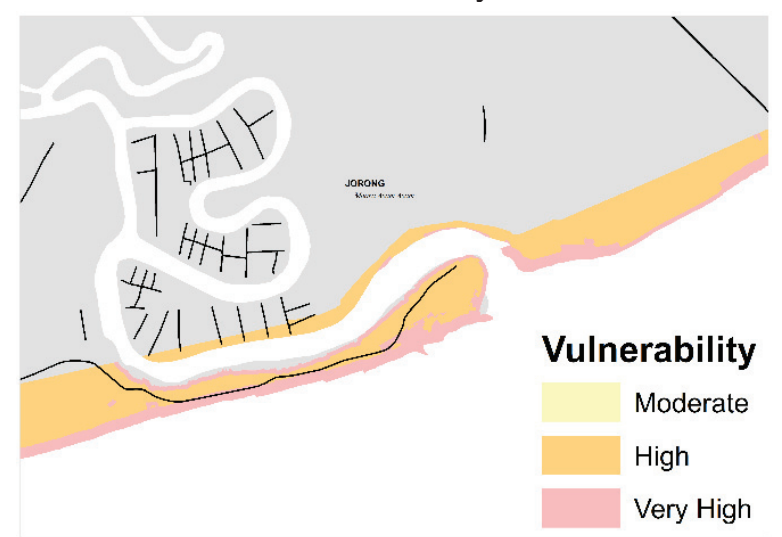

Fig. 3. Coastal erosion vulnerability map

\subsection{Consequence assessment}

The level of consequence is based on the estimation of the adverse impacts that may arise from the erosion hazard that occurs in Muara Asam Asam Village. The more important a location is, which is characterized by population density, distribution of ecological zones, the presence of historical sites, and the presence of massive economic activity, then the location will have major consequences if coastal erosion continues, because it will affect the economic, social and environmental structure. at that location.

The four parameters selected in the consequence level analysis are based on previous studies conducted in Aveiro, Portugal and in Macaneta Spit, Mozambique [18]. Parameters of population density, economic level, distribution of ecological areas, and distribution of historical buildings. Each is classified into 5 different values, according to the classification shown in Table 3.

Table 3. Classification of consequence parameters

\begin{tabular}{|c|c|c|c|c|c|c|}
\hline \multirow{2}{*}{ No } & \multirow{2}{*}{ Parameter } & \multicolumn{5}{|c|}{ Level of Consequence } \\
\hline & & Very Low & Low & Moderate & High & Very High \\
\hline 1 & $\begin{array}{l}\text { Population density } \\
\left(\text { Jiwa/ } / \mathrm{Km}^{2}\right)\end{array}$ & 500 & $\begin{array}{l}500- \\
1000\end{array}$ & $\begin{array}{l}1000- \\
2000\end{array}$ & $2000-4000$ & $>4000$ \\
\hline 2 & Number of workers & 0 & $0-10$ & $10-30$ & $30-50$ & $>50$ \\
\hline 3 & $\begin{array}{l}\text { Ecological protection } \\
\text { zones }\end{array}$ & $\begin{array}{l}\text { Not an } \\
\text { ecological } \\
\text { protection } \\
\quad \text { zone }\end{array}$ & $\begin{array}{l}\text { Strategic } \\
\text { agricultur } \\
\text { al zones }\end{array}$ & $\begin{array}{l}\text { Ecological } \\
\text { conservati } \\
\text { on zones }\end{array}$ & $\begin{array}{l}\text { Ecological } \\
\text { protected } \\
\text { zones }\end{array}$ & $\begin{array}{l}\text { National } \\
\text { parks }\end{array}$ \\
\hline 4 & Historical sites & $\begin{array}{l}\text { No historical } \\
\text { site }\end{array}$ & $\begin{array}{l}\text { There are } \\
\text { several } \\
\text { historical } \\
\text { construct } \\
\text { ions }\end{array}$ & $\begin{array}{l}\text { There are } \\
\text { historical } \\
\text { constructio } \\
\text { ns and } \\
\text { community } \\
\text { activities } \\
\text { in it }\end{array}$ & $\begin{array}{l}\text { Regional } \\
\text { historic } \\
\text { construction }\end{array}$ & $\begin{array}{l}\text { National } \\
\text { Monument }\end{array}$ \\
\hline
\end{tabular}

Source: [18] 
The following is an empirical assessment of the four parameters used as input in assessing the level of consequences of coastal erosion in Muara Asam Asam Village (Figure 4).

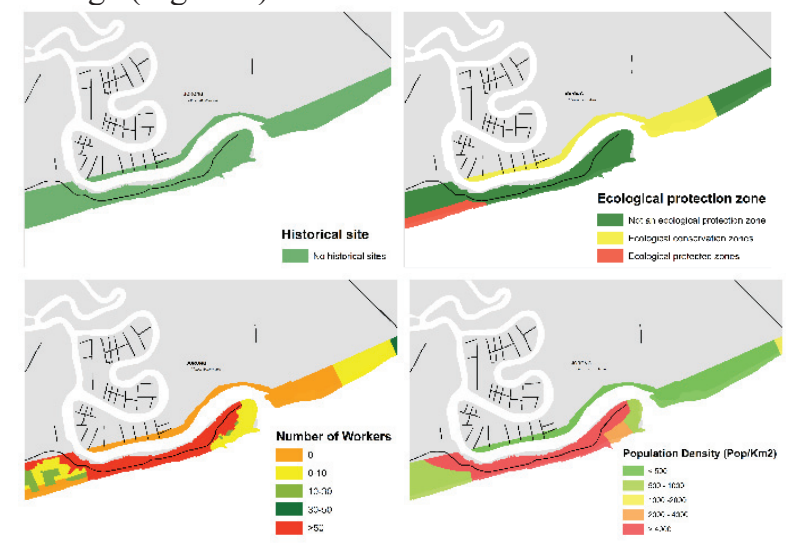

Fig. 4. Compiling parameters of consequence assessment

The economic activity is measured based on the estimated number of workers in each land unit indicated as the location of economic activity, such as agricultural land, settlement areas, ports, and industrial areas. Economic activities in Muara Asam Asam Village are dominated by the agricultural and fisheries sectors and are concentrated around the center of settlements on the west side of the river and towards the mainland. Therefore, in its coastal area, the dominant sector is fisheries, which is marked by the number of public ports and fishing boats as well as a main mode of river transportation in Tanah Laut Regency.

The level of population density is generally classified as high to very high in the settlement center of Muara Asam Asam Village, and low in other parts, because there are almost no buildings in the agricultural area or bare land on the east side of the river and the westernmost side of the study area. There are no historical sites around the coast of Muara Asam Asam Village, so the entire study area is classified as low on this parameter.

The ecological protected area is extracted based on the spatial plan map of the Tanah Laut Regency, so that the classification is very low (not an ecological protection area), low (agricultural area), medium (ecological conservation area) scattered in mangrove forest on the north side of the river, and highly classified in the coastal protection area located at the western part of the study area. The consequence assessment to coastal erosion produces an output in the form of a consequence level map shown in Figure 5.

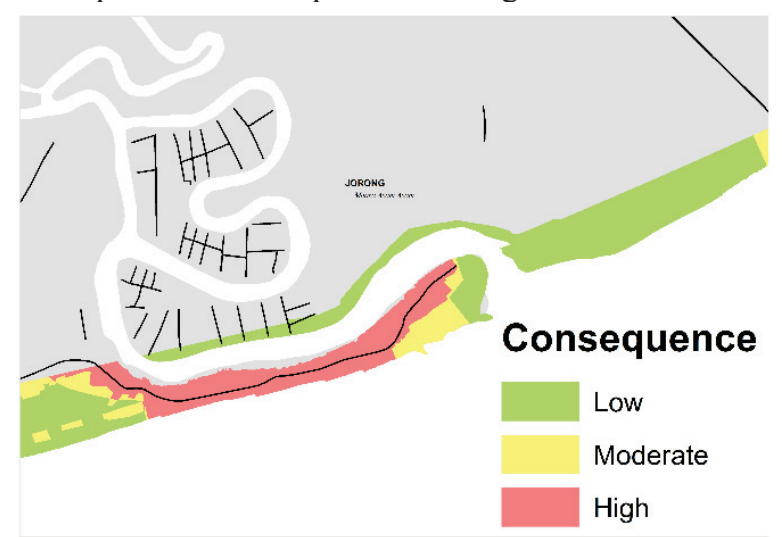

Fig. 5. Coastal erosion consequence map

Based on the results of the assessment shown in Figure 5, it is known that the consequence level map has a different value distribution from the level of vulnerability, because in this analysis it does not use the proximity factor to the coastline as a parameter or weight compiler. The weights for each parameter in the consequence analysis are the same, resulting in a proportional mix. The high consequence level is centered on the residential area in Muara Asam Asam Village, because from various parameters, this area is the biggest consequence if coastal erosion continues, because all economic and social activities are linked and centered in the settlement area of Muara Asam Asam Village.

\subsection{Risk assessment}

The level of risk is the relationship between the level of vulnerability and the level of consequences for the catastrophic erosion that occurred in Muara Asam Asam Village. This relationship is arranged in the risk level matrix shown in Table 4.

Table 4. Risk matrix

\begin{tabular}{|c|c|c|c|c|c|c|}
\hline & & & & sequence In & & \\
\hline & & Very low & Low & Moderate & High & Very high \\
\hline & Very low & Very low risk & $\begin{array}{l}\text { Very low } \\
\text { risk }\end{array}$ & $\begin{array}{l}\text { Very low } \\
\text { risk }\end{array}$ & Low risk & $\begin{array}{l}\text { Moderate } \\
\text { risk }\end{array}$ \\
\hline$\stackrel{0}{E}$ & Low & Very low risk & $\begin{array}{c}\text { Very low } \\
\text { risk }\end{array}$ & Low risk & $\begin{array}{l}\text { Moderate } \\
\text { risk }\end{array}$ & High risk \\
\hline \% & Moderate & Very low risk & Low risk & $\begin{array}{l}\text { Moderate } \\
\text { risk }\end{array}$ & High risk & $\begin{array}{l}\text { Very high } \\
\text { risk }\end{array}$ \\
\hline$\frac{\bar{D}}{3}$ & High & Low risk & $\begin{array}{l}\text { Moderate } \\
\text { risk }\end{array}$ & High risk & $\begin{array}{l}\text { Very high } \\
\text { risk }\end{array}$ & $\begin{array}{l}\text { Very high } \\
\text { risk }\end{array}$ \\
\hline & Very high & Moderate risk & High risk & $\begin{array}{l}\text { Very high } \\
\text { risk }\end{array}$ & $\begin{array}{l}\text { Very high } \\
\text { risk }\end{array}$ & $\begin{array}{l}\text { Very high } \\
\text { risk }\end{array}$ \\
\hline
\end{tabular}

From the results of this analysis is the final result of the risk assessment of coastal erosion in Muara Asam
Asam Village and it is known that the distribution of zones that have a high level of risk requires special 
attention by making them a priority area for handling at the recommendation formulation stage. The results of the risk level analysis are shown in Figure 6.

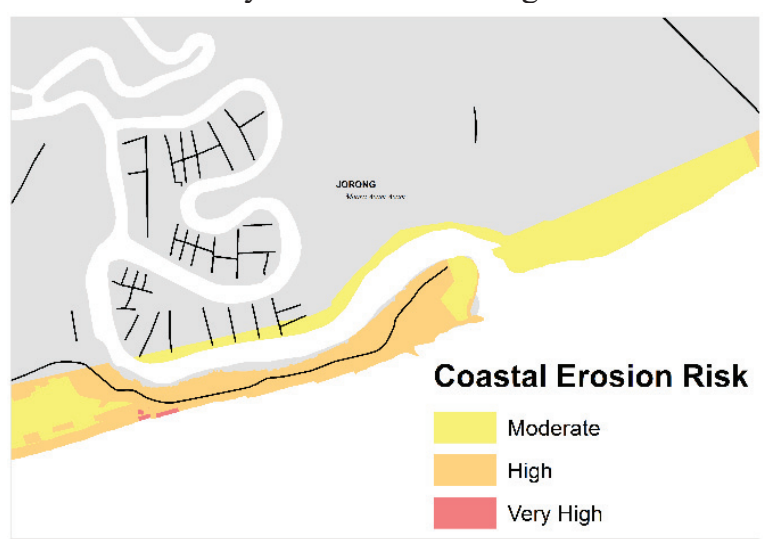

Fig. 6. Coastal erosion risk map

Based on the spatial description presented in Figure 14 , the high-risk zones is concentrated on the western side of the settlement area, which in this part has not been maximally protected by erosion-retaining coastal construction. Meanwhile, the high-risk classification is evenly distributed in the residential area of Muara Asam Asam Village, which is located on the west side of the river and part of the industrial area on the easternmost side of the study area. Meanwhile, other areas, namely agricultural areas, open land and mangrove forests, are classified as zones with a medium risk level. So it can be concluded that the control of coastal erosion should be centered on the side of settlements classified as high and moderate risk, as well as in industrial areas.

\section{Conclusion}

The results of the study can be concluded that the coastal area of Muara Asam Asam has a high risk of coastal erosion, especially in the coastal settlement area on the west side of the study area, due to the lack of implementation of coastal hard structures such as groynes, detached breakwaters and artificial submerged reefs that can be built to significantly reduce coastal erosion. This hazard also threatens industrial activities on the eastern part of Asam-Asam Village, due to high annual erosion rate. It is necessary to combine the development of erosion-preventing infrastructure with a coastal zoning policy to protect the socio-economic activities of the community as well as the ecological environmental resources in the coastal area of Muara Asam Asam as part of sustainable coastal development.

The author would like to thank the Local Government of Tanah Laut Regency, Especially the Office of Public Works, Spatial Planning and Land, who have provided us with the opportunity to research the dynamics of the coastal area in Muara Asam-Asam.

\section{References}

1. C. Brown, E. Corcoran, P. Herkenrath, and J. Thonell, Marine and Coastal Ecosystems and Human Well-Being (UNEP, Nairobi, 2006)
2. IPPC, IPCC First Assess. Rep. 48, 1334 (1992)

3. S. P. Leatherman, R. J. Nicholls, K. C. Dennis, and K. C. Dennis2, Source J. Coast. Res. J. Coast. Res. SI 15 (1995)

4. E. R. Thieler and E. S. Hammar-Klose, OpenFile Rep. 00-179 1 (1999)

5. C. Sharples, Wollongong Pap. Marit. Policy 16, 235 (2006)

6. M. Mokrech, S. Hanson, R. J. Nicholls, J. Wolf, C. M. Fontaine, S. Nicholson-cole, S. R. Jude, J. Leake, A. R. Watkinson, M. D. A. Rounsevell, J. A. Lowe, J. W. Hall, M. Mokrech, S. Hanson, R. J. Nicholls, J. Wolf, M. Walkden, C. M. Fontaine, S. N. Simon, R. J. James, P. Stansby, A. R. Watkinson, M. D. A. Rounsevell, J. A. Lowe, and J. W. Hall, J. Coast Conserv. 15, (2011)

7. O. Ferreira, C. Viavattene, J. Jiménez, A. Bole, T. Plomaritis, S. Costas, and S. Smets, E3S Web Conf. 7, 1 (2016)

8. M. H. Faber, Statistics and Probability Theory In Pursuit of Engineering Decision Support, 18 th ed. (Springer, Norfolk, Virginia, U.S.A., 2012)

9. UNISDR, 2009 UNISDR Terminology on Disaster Risk Reduction (United Nations International Strategy for Disaster Reductiom (UNISDR), Geneva, 2009)

10. ISO, Risk Management - Vocabulary (Swiss, 2009)

11. E. Iriadenta, Fish Sci. 3, (2013)

12. J. Hinkel and R. J. T. Klein, Glob. Environ. Chang. 19, 384 (2009)

13. C. D. B. Coelho, Riscos de Exposição de Frentes Urbanas Para Diferentes Intervenções de Defesa Costeira, Universidade de Aveiro, 2005

14. J. J. Ras, Hikayat Banjar Translated by Siti Hawa Salleh (Percetakan Dewan Bahasa dan Pustaka, Selangor Darul Ehsan, Malaysia, 1990)

15. E. Iriadenta, Fish Sci. 4, 64 (2013)

16. Darmiati, I. W. Nurjaya, and A. S. Atmadipoera, 12, 211 (2020)

17. C. Coelho, M.-J. Granjo, and C. SeguradoSilva, Recur. Hídricos 28, (2007)

18. P. Narra, C. Coelho, F. Sancho, and J. Palalane, Ocean Coast. Manag. 142, 1 (2017) 